\author{
초고강도 베이나이트강의 미세조직과 기계적 성질에 미치는 \\ 탄소함량과 항온열처리 온도의 영향

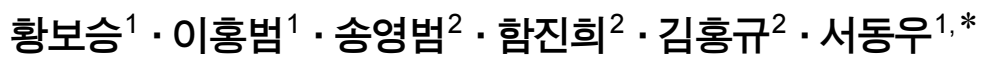 \\ 1 포항공과대학교 철강대학원 \\ 2국방과학연구소
}

\title{
Influence of Carbon Content and Isothermal Heat Treatment Temperature on the Microstructure and Mechanical Properties of Ultra-High Strength Bainitic Steels
}

\author{
Seung Hwangbo ${ }^{1}$, Hong-Bum Lee ${ }^{1}$, Young-Beum Song ${ }^{2}$, Jinhee Ham ${ }^{2}$, Hong-Kyu Kim ${ }^{2}$, and Dong-Woo Suh ${ }^{1}$ * \\ ${ }^{1}$ Graduate Institute of Ferrous Technology, Pohang University of Science and Technology, Pohang 37673, Republic of Korea \\ ${ }^{2}$ Agency for Defense Development, Daejeon 34186, Republic of Korea
}

\begin{abstract}
The effect of carbon content and isothermal heat treatment conditions on the microstructure evolution and mechanical properties of ultra-high strength bainitic steels was investigated. A reduction in carbon content from $0.8 \mathrm{wt} \%$ to $0.6 \mathrm{wt} \%$ in super-bainite steel with typical chemistry effectively improved not only the Charpy impact toughness but also the strength level. This suggests that reducing the carbon content is a very promising way to obtain better mechanical balance between strength and impact toughness. The higher Charpy impact toughness at a lower carbon content of $0.6 \mathrm{wt} \%$ is thought to result from a reduction in austenite fraction, and refinement of the austenite grain. The coarse austenite grains have a detrimental effect on impact toughness, by prematurely transforming to deformation-induced martensite during crack propagation. Mechanical properties were also affected by the isothermal treatment temperature. The lower isothermal temperature enhanced the formation of bainitic ferrite with a refined microstructure, which has a beneficial influence on strength, but reduces impact toughness. The lower impact toughness at lower isothermal temperature is attributed to the sluggish redistribution of carbon from the bainitic ferrite into the surrounding austenite. Higher solute carbon in the bainitic ferrite contributes to an increase of strength, but at the same time, encourages a propensity to cleavage fracture.
\end{abstract}

(Received March 6, 2019; Accepted May 2, 2019)

Keywords: high strength, bainitic ferrite, heat treatment, austenite, impact toughness

\section{1. 서 론}

초고강도 베이나이트 강은 높은 농도의 $\mathrm{C}(1 \mathrm{wt} \%$ 내외 $)$ 및 $\mathrm{Si}$ 을 함유한 강재로서 오스테나이트화 처리 후 비교적 저온 $\left(200 \sim 300^{\circ} \mathrm{C}\right)$ 에서 장시간 항온열처리 (오스템퍼링) 를 통해 나노구조의 베이나이트와 잔류오스테나이트 복합 조직을 구현하여 인장강도 $2.0 \mathrm{GPa}$ 수준의 초고강도를 얻을 수 있는 강재이다 [1-3]. 기본적인 합금설계 및 열처리 공정

- 황보승: 석사, 이홍범: 박사과정, 송영범 - 함진희 - 김홍규: 연구원, 서동우: 교수 *Corresponding Author: Dong-Woo Suh

[Tel: +82-54-279-9030, E-mail: dongwoo1@postech.ac.kr]

Copyright (c) The Korean Institute of Metals and Materials
에 대한 개념은 2002년 영국 캠브리지 대학교의 H.K.D.H. Bhadeshia 교수에 의해 제안되었다. 이후 여러 연구자에 의 해 super bainite, strong bainite, hard bainite, lowtemperature bainite 로 불리어지고 연구되었으나 기본적으 로 거의 유사한 합금성분 및 공정조건을 바탕으로 하고 있 으며 보고되고 있는 미세조직 또한 유사하다 $[2,4]$.

초고강도 베이나이트강의 높은 $\mathrm{C}$ 함량은 마르텐사이트 변태개시 온도 $\left(\mathrm{M}_{\mathrm{s}}\right)$ 를 $200{ }^{\circ} \mathrm{C}$ 이하로 낮춤으로써 200 $300{ }^{\circ} \mathrm{C}$ 온도 범위에서 항온 열처리에 의해 나노 크기의 매 우 미세한 베이나이트 형성을 가능하게 한다 [5-7]. 또한 $\mathrm{Si}$ 첨가는 항온 열처리 중 cementite 석출을 억제하여 최 
종 미세조직에 다량의 오스테나이트를 잔류시킴으로써 변 태유기소성 (transformation-induced plasticity) 기구에 의 해 균일 연신율을 향상시키는데 기여하는 것으로 알려져 있다 [8-10].

비교적 단순한 성분 계를 활용하여 초고강도와 고연신을 동시에 확보할 수 있는 것으로 알려진 초고강도 베이나이 트 강은 개발 초기부터 차세대 철강재료로서 큰 기대를 모 았으며 이를 수송기계, 발전용 터빈 샤프트 등에 적용하기 위해 많은 연구가 진행되었다 $[2,11,12]$. 그러나 현재까지 초고강도 베이나이트 강이 실제로 적용된 곳은 천공형 장 갑판재와 같이 매우 특수한 응용 분야로 제한되어 있다. 초고강도 베이나이트 강의 상업적 적용 확대가 더딘 이유 로는 높은 $\mathrm{C}$ 함량에 따른 용접 문제와 매우 낮은 상온충 격인성을 들 수 있다 $[13,14]$. 용접성의 경우에는 다른 용 접방법을 적용하거나 또는 용접조건 최적화를 통하여 극복 할 수 있는 여지가 존재한다. 그러나 상온충격인성은 구조 물 설계 변경 등 다른 방안을 통하여 해결하기 매우 어려 운 문제이므로 재료 자체의 성능 향상에 대한 연구가 필수 적이다.

본 연구에서는 $\mathrm{C}$ 함량 저감 및 항온열처리 온도 조건 의 제어에 따른 영향을 살펴봄으로써 초고강도 베이나이 트 강재의 강도 및 연신율의 저하를 최소화하면서도 강 재의 상온충격인성을 개선할 수 있는 방안을 찾아보고자 하였다. 앞에서 언급한 바와 같이 높은 $\mathrm{C}$ 함량은 초고강 도 베이나이트 강의 마르텐사이트 변태 개시 온도를 낮 추어 비교적 저온에서 베이나이트 항온변태를 가능하게 하는 핵심적인 인자이지만, 동시에 조대한 크기의 오스테 나이트 결정립을 잔류시킴으로써 상온충격인성 열화를 촉 진할 가능성이 있다 [15-17]. 이에 $\mathrm{C}$ 함량이 저감된 조 건에서 잔류 오스테나이트의 분율, 형상 변화가 초고강도 베이나이트 강의 충격인성을 비롯한 기계적 특성에 미치 는 영향을 고찰하고자 하였다. 또한 잔류 오스테나이트 특성과 베이나이트 내 고용 $\mathrm{C}$ 함량 등 강재의 기계적 특성에 큰 영향을 미칠 수 있는 미세조직학적 인자들은 항온변태온도에도 크게 영향을 받을 가능성이 높으므로 이에 대해서도 고찰하였다.

\section{2. 실험방법}

실험에 사용된 강재의 화학조성은 표 1 과 같다. 합금 I 은 초고강도 베이나이트 강에 대해 일반적으로 알려진 조 성을 가지고 있으며, 합금 $\mathrm{II}$ 는 합금 I 대비 C 함량을 저 감한 성분계로 설계하였다. $\mathrm{C}$ 함량을 $0.6 \mathrm{wt} \%$ 이하로 낮
Table 1. Chemical composition of investigated alloys (wt $\%$ ).

\begin{tabular}{cccccc}
\hline & $\mathrm{C}$ & $\mathrm{Si}$ & $\mathrm{Mn}$ & $\mathrm{Mo}$ & $\mathrm{Cr}$ \\
\hline Alloy I & 0.84 & 1.3 & 2.0 & 0.27 & 1.2 \\
\hline Alloy II & 0.63 & 1.3 & 1.9 & 0.26 & 1.2 \\
\hline
\end{tabular}

추는 경우에는 마르텐사이트 변태 개시 온도가 $200{ }^{\circ} \mathrm{C}$ 이 상으로 상승할 가능성이 높다. 따라서 $200 \sim 300{ }^{\circ} \mathrm{C}$ 항온변 태온도를 적용하여 나노 크기의 미세한 베이나이트를 확보 하기 위해서는 최소한 $0.6 \mathrm{wt} \%$ 수준의 $\mathrm{C}$ 함량이 필요할 것으로 판단하여 합금 $\mathrm{II}$ 의 $\mathrm{C}$ 함량을 결정하였다.

합금은 진공용해를 통해 $40 \mathrm{~kg}$ 잉곳(ingot)으로 제조하였 다. 각 잉곳은 $1200{ }^{\circ} \mathrm{C}$ 에서 2 시간 동안 균질화 처리하 고, $1000{ }^{\circ} \mathrm{C}$ 이상에서 마무리 압연 하여 최종적으로 15 $\mathrm{mm}(\mathrm{T}) \times 200 \mathrm{~mm}(\mathrm{~W}) \times 1750 \mathrm{~mm}(\mathrm{~L})$ 크기의 강판으로 제조 하였다.

합금의 오스테나이트화 처리 및 오스템퍼링 온도는 선팽 창 곡선 측정 장치 (Dilatometer) 를 이용하여 오스테나이 트 변태 종료온도 $\left(\mathrm{A}_{3}\right)$, 마르텐사이트 변태개시온도 $\left(\mathrm{M}_{\mathrm{s}}\right)$ 를 평가하여 결정하였다. 선팽창 곡선 측정은 지름 $3 \mathrm{~mm}$, 길이 $10 \mathrm{~mm}$ 원통형 시편을 사용하여 진행하였다.

열처리된 합금의 기계적 특성은 인장시험, 경도시험 및 샤르피 충격시험을 통하여 평가하였다. 기계적 특성 평가 를 위한 시편은 상자로와 염욕로를 이용하여 열처리한 후 시험편을 제작하였다. 인장시험 시편은 ASTM E8M subsize 규격으로 가공하였고, 샤르피 충격시험 시편은 ASTM A370 standard size 규격으로 가공하였다. 샤르피 충격시험 은 상온에서 진행하였다. 경도는 비커스 경도계를 이용하 여 하중 $10 \mathrm{~kg}$ 의 조건으로 평가하였다.

강재의 미세조직과 충격파면은 $\mathrm{FE}-\mathrm{SEM}$ 을 이용하여 관 찰하였다. 미세조직 관찰을 위해서 연마지와 연마액을 사 용하여 표면을 연마한 후 나이탈 (Nital) 부식액을 이용하 여 표면을 부식시킨 후 관찰하였다.

열처리에 따른 강재 내 잔류 오스테나이트 분율과 $\mathrm{C}$ 농 도는 $\mathrm{X}$-선 회절 (XRD) 피크 분석을 통해 확인하였다. 우

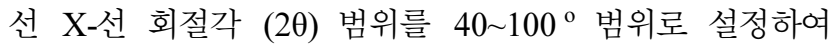
$\mathrm{FCC}$ 및 $\mathrm{BCC}$ 피크를 각각 4개씩 검출한 후 적분강도를 계산하여 오스테나이트의 분율을 계산하였다 [31]. 또한 (200) 오스테나이트 피크 위치 변화로부터 오스테나이트 내 $\mathrm{C}$ 농도를 평가하였다 [32,33]. 시편 준비는 기본적으로 미 세조직 관찰을 위한 시편과 동일한 방법으로 준비하였고, 표면부 변형층을 제거하기 위해 최종 연마단계에서는 전기 화학적 방법을 사용하여 연마하였다. 


\section{3. 실험 결과}

\section{1. 상변태 거동}

그림 1 은 합금 $\mathrm{I}$ 과 $\mathrm{II}$ 를 상온에서 $950{ }^{\circ} \mathrm{C}$ 까지 $1{ }^{\circ} \mathrm{C} / \mathrm{s}$ 으로 승온하고 3 분 유지 후 $30{ }^{\circ} \mathrm{C} / \mathrm{s}$ 으로 냉각한 조건에서 측정한 선팽창 곡선이다. 합금 $\mathrm{I}$ 과 II의 선팽창 거동으로부 터 승온 시 오스테나이트 변태 종료온도는 약 $822^{\circ} \mathrm{C}$ 와 $802{ }^{\circ} \mathrm{C}$, 냉각 시 마르텐사이트 변태개시온도는 약 $101{ }^{\circ} \mathrm{C}$ 및 $172{ }^{\circ} \mathrm{C}$ 로 평가되었다. 합금 $\mathrm{II}$ 의 경우, $\mathrm{C}$ 함량 저감 에 의해 마르텐사이트 변태개시 온도가 상승하였지만, 200 $\sim 300{ }^{\circ} \mathrm{C}$ 온도 범위에서 베이나이트 형성을 위한 항온변태 열처리를 적용하는 데는 문제가 없다고 판단되었다. 그림 1 에서 측정된 상변태 온도를 바탕으로 합금을 $950{ }^{\circ} \mathrm{C}$ 에서 오스테나이트화 처리 한 후, $200 \sim 300{ }^{\circ} \mathrm{C}$ 온도 범위에서 항온변태 처리하였다. 항온변태열처리 과정에서의 베이나 이트 변태거동을 확인하기 위한 시편 선팽창 측정 결과를 그림 2에 나타내었다. 그림 2에서 화살표로 표시한 부분은 항온변태 영역 선팽창 곡선에서 나타난 첫 번째 극대점으 로서 이에 해당하는 시간을 베이나이트 변태완료 시점으로 고려하였다. $250{ }^{\circ} \mathrm{C}$ 에서 항온변태 처리하는 경우, 합금 I 과 II 모두 약 60 시간 이내의 항온변태 처리에 의해 베 이나이트 변태가 거의 완료됨을 알 수 있다 (그림 $2 \mathrm{a}$, b). 합금 II 의 경우에는 $\mathrm{C}$ 함량 저감에 의해 베이나이트 변태가 합금 I의 경우보다 단시간에 개시되는 것을 알 수 있었고 베이나이트 변태 완료 시간 또한 단축되었다. 합금 II의 항온변태 온도에 따른 베이나이트 변태 거동을 측정 한 결과를 보면 (그림 $2 \mathrm{~b}, \mathrm{c}, \mathrm{d}$ ), $200 \sim 300^{\circ} \mathrm{C}$ 온도 범 위에서 항온변태온도가 낮아질수록 베이나이트 상변태 개 시와 종료를 위해 보다 장시간의 열처리가 필요하다는 것 을 알 수 있다. 즉, $300{ }^{\circ} \mathrm{C}$ 의 항온변태조건에서는 5 시간 이내에 베이나이트 변태가 완료되지만, 항온변태온도가 $200{ }^{\circ} \mathrm{C}$ 로 낮아지는 경우에는 약 100 시간 정도의 항온변태 처리가 필요하다. 이는 항온변태온도가 낮아질수록 베이나 이트 변태를 위한 구동력은 증가하지만, 베이나이트 변태
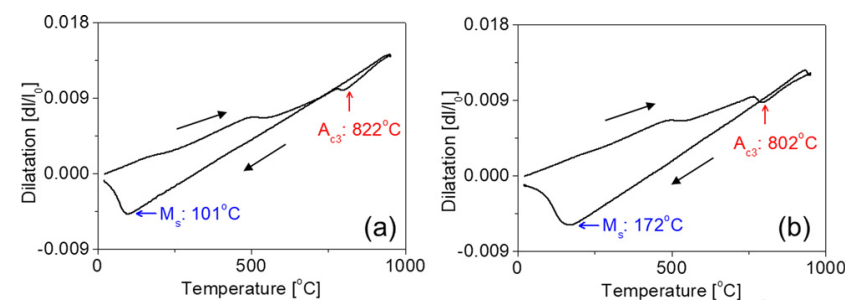

Fig. 1. Dilatation behavior of (a) alloy I and (b) alloy II upon heating to $950{ }^{\circ} \mathrm{C}$, followed by cooling to room temperature.
가 진행되기 위하여 필요한 $\mathrm{C}$ 확산이 느려지기 때문이다 [6,18-20].

합금 I과 II의 상변태 거동 분석을 통해 오스테나이트화 처리 후 $200 \sim 300{ }^{\circ} \mathrm{C}$ 온도 범위에서 베이나이트 변태를 위한 항온열처리 적용이 가능하다고 판단되었으므로 합금 의 기계적 특성 평가를 위하여 상자로와 염욕로를 이용하 여 그림 3과 같은 조건으로 열처리를 실시하였다. C 함량 의 영항을 살펴보기 위하여 $250{ }^{\circ} \mathrm{C}$ 에서 항온변태 처리한 합금 I과 II를 비교 검토하였고, 항온변태온도의 영향을 고 찰하기 위하여 합금 $\mathrm{II}$ 에 대해 $200,250,300{ }^{\circ} \mathrm{C}$ 에서 항 온변태 열처리 후 미세조직과 기계적 특성을 분석하였다. 각 항온변태온도에서 유지시간은 각각 $250,72,8$ 시간으 로 베이나이트 변태가 충분히 진행되어 최종 냉각과정에서 마르텐사이트 변태가 발생하지 않는 조건으로 열처리 하였 다. 따라서 모든 시편의 최종 미세조직은 베이니틱 페라이 트와 잔류 오스테나이트로 이루어진 이상 (Dual phase) 조 직이다.
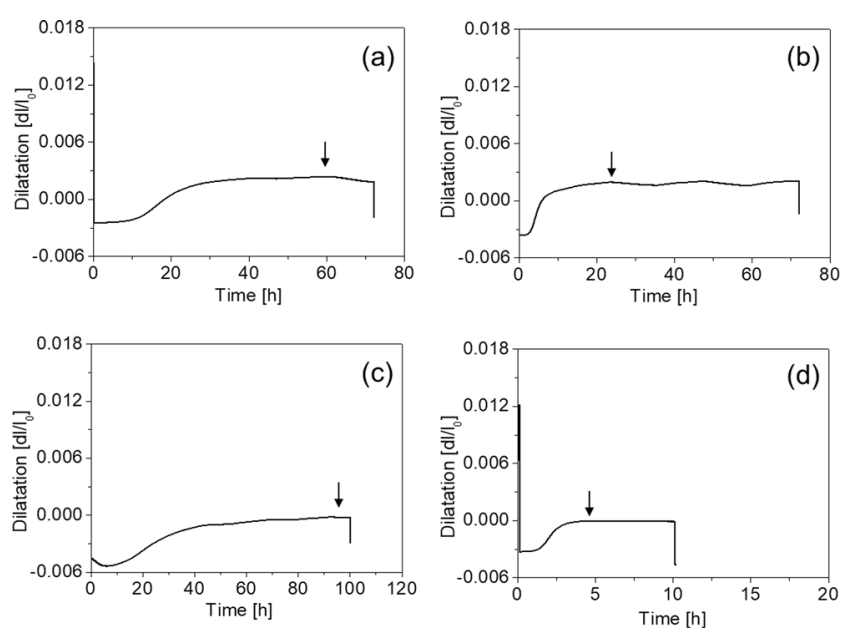

Fig. 2. Dilation behavior during isothermal treatment: (a) alloy I at $250{ }^{\circ} \mathrm{C}$, (b) alloy II at $250{ }^{\circ} \mathrm{C}$, (c) alloy II at $200{ }^{\circ} \mathrm{C}$ and (d) alloy II at $300{ }^{\circ} \mathrm{C}$ (arrows indicate the first saturation points in the dilatation curves).

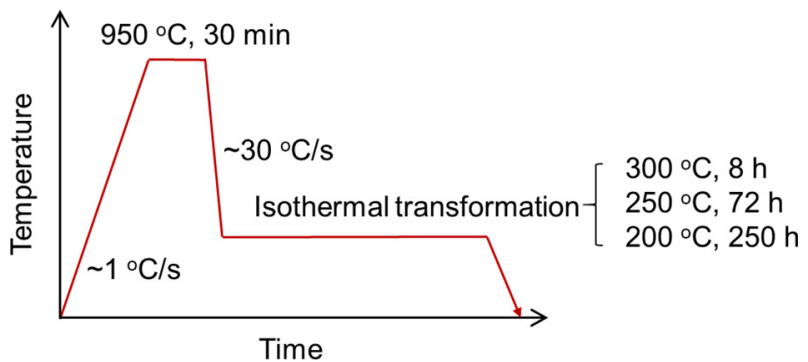

Fig. 3. Heat treatment path of investigated alloys. 


\section{2. 탄소함량에 따른 미세조직과 기계적 특성}

$250{ }^{\circ} \mathrm{C}$ 에서 72 시간 항온변태 열처리한 합금 $\mathrm{I}$ 과 $\mathrm{II}$ 의 미세조직을 그림 4에 나타내었다. 두 합금 모두에서 압연 방향으로 연신된 형태의 미세조직을 확인할 수 있으며 이 러한 영역은 응고 시 형성된 합금원소 편석층이 열간압연 에 의해 연신되어 나타나는 것이다. 이렇게 연신된 영역에 서는 편석에 의해 $\mathrm{Mn}$ 농도가 높으므로 상온에서 오스테나 이트가 잔류할 가능성이 높다. 실제로 연신된 영역을 확대 하여 보면 (그림 $4 \mathrm{~b}, \mathrm{~d}$ ) 침상형 베이니틱 페라이트로 변 태한 영역 사이에 잔류 오스테나이트로 판단되는 미세조직 이 관찰되는 것을 알 수 있다. $\mathrm{C}$ 의 함량이 $0.8 \mathrm{wt} \%$ 인 합금 I에서는 비교적 조대한 크기의 오스테나이트를 관찰 할 수 있으며 오스테나이트 분율 또한 $33.5 \%$ 수준으로 평 가되었다 (그림 $4 \mathrm{a}, \mathrm{b}$ ). C 함량을 저감한 합금 II의 경 우에도 연신된 미세조직은 여전히 관찰되지만, 잔류 오스 테나이트 결정립 크기는 합금 I과 비교하여 미세화되었고, 분율도 $18.7 \%$ 수준으로 감소하였다 (그림 $4 \mathrm{c}, \mathrm{d}$ ).

$\mathrm{C}$ 함량 저감에 따른 잔류 오스테나이트 결정립 크기와
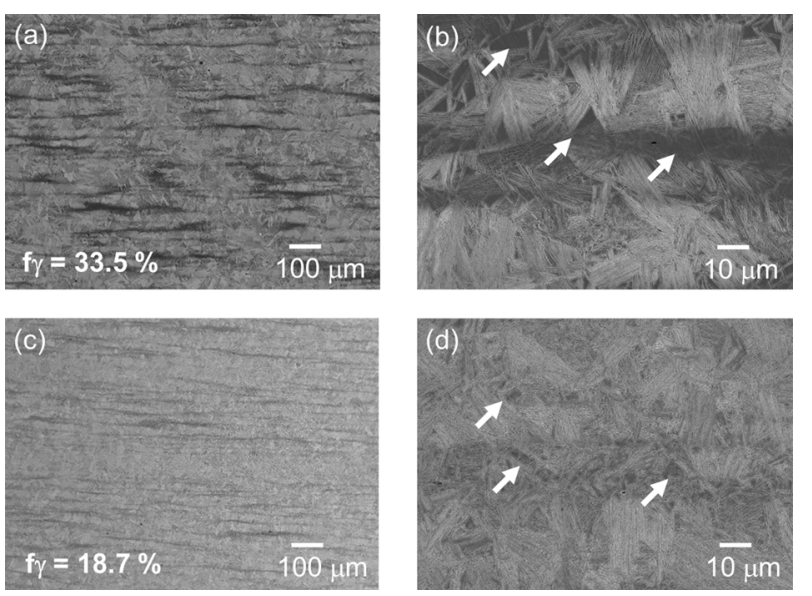

Fig. 4. Microstructure of alloy I $(a, b)$ and alloy II (c, d) after heat treatment (arrows indicate the microstructure presumed to be retained austenite).
분율 감소는 베이니틱 페라이트 형성에 따른 오스테나이트 로의 C 재분배와 관련이 있다 [19,21]. 합금의 C 함량이 감소하면 동일한 분율의 베이니틱 페라이트가 형성될 때 오스테나이트로 재분배 되어야 할 $\mathrm{C}$ 양이 감소하게 된다. 이 때문에 합금의 $\mathrm{C}$ 함량이 낮은 경우, 잔류 오스테나이트 의 $\mathrm{C}$ 함량이 전단변태 (displacive transformation)에 의해 베이니틱 페라이트 형성이 열역학적으로 어려워지는 $\mathrm{T}_{\mathrm{o}}$ (또 는 $\mathrm{T}_{\mathrm{o}}{ }^{\prime}$ ) 수준에 도달하기 위해서는 더 높은 분율의 베이니 틱 페라이트가 형성되어야 한다. 따라서 $\mathrm{C}$ 함량이 낮은 합 금 II의 경우, 동일한 온도에서 항온변태 처리했음에도 불 구하고 합금 I과 비교하여 더 많은 베이니틱 페라이트가 형성되게 되며 따라서 잔류 오스테나이트 분율이 감소하고, 결정립의 크기도 미세하게 된다.

그림 5 에서 $\mathrm{C}$ 함량에 따른 경도와 상온충격인성의 변화 를 확인할 수 있다. $\mathrm{C}$ 함량 저감에도 불구하고 합금의 경 도가 다소 향상되는 것으로 나타났다. 이는 합금 합금 II $(0.6 \mathrm{C})$ 의 경우, 항온변태 열처리 후 오스테나이트 보다 경 한 조직인 미세한 베이니틱 페라이트의 분율이 증가하였기 때문이다. 경도의 상승에도 불구하고 상온충격인성 또한 $\mathrm{C}$ 함량 저감에 따라 상당히 개선되는 것으로 나타났는데 이 는 앞에서 언급한 잔류 오스테나이트의 특성 변화와 관련 이 있는 것으로 생각된다. 기존의 연구결과에 의하면 초고 강도 베이나이트강의 매우 낮은 상온충격인성은 잔류 오스 테나이트의 낮은 기계적 안정성에 기인하는 것으로 보고되 고 있다 [15,22-24]. 즉 충격시험 시 균열 선단에 존재하 는 조대한 잔류 오스테나이트 결정립은 기계적 안정성이 낮아 응력 및 변형의 영향으로 마르텐사이트로 쉽게 변태 하게 되고 [22,23,34], 이에 따라 균열의 전파가 용이하게 되어 낮은 상온충격인성을 나타내게 된다는 것이다. 두 합 금 모두 $250{ }^{\circ} \mathrm{C}$ 에서의 항온열처리에 의해 베이니틱 페라 이트 형성이 거의 완료되는 단계에서 잔류 오스테나이트 내의 $\mathrm{C}$ 농도는 크게 다르지 않을 것이라 생각되며 실제 측정 결과 또한 유사하였다 (그림 6). 하지만, 합금의 $\mathrm{C}$
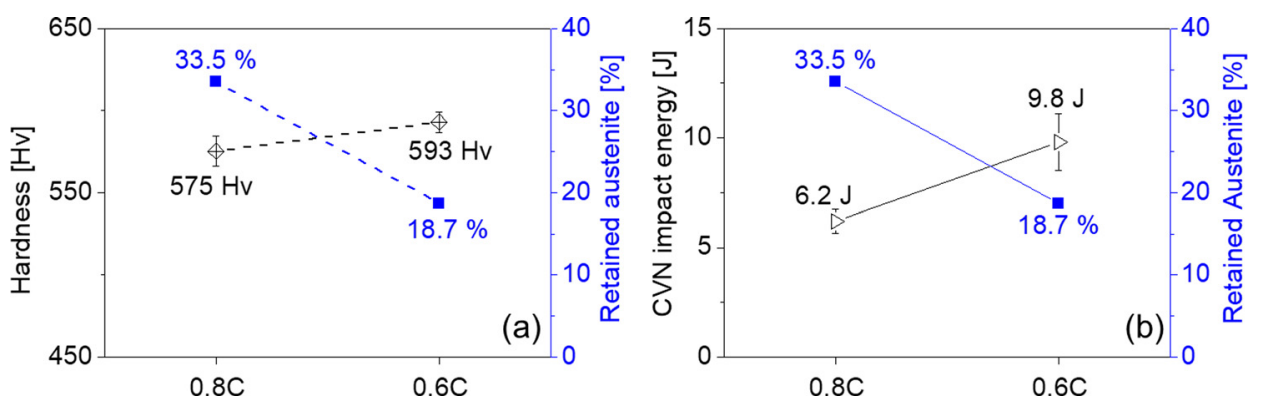

Fig. 5. (a) Hardness and (b) Charpy impact energy of investigated alloys. 


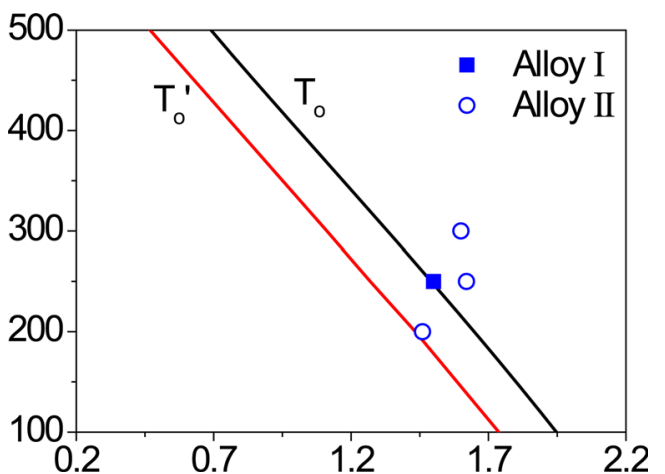

Fig. 6. $T_{0}$ and $T_{0}$ ' lines with carbon content in the retained austenite.
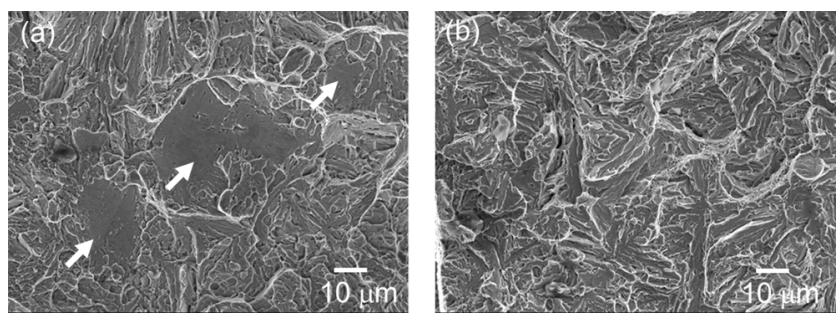

Fig. 7. Fracture surface after Charpy impact test; (a) alloy I, (b) alloy II.

함량이 저감되면 잔류 오스테나이트 결정립이 미세화되고 이에 따라서 기계적 안정성이 높아지게 된다. 또한 오스테 나이트 결정립 미세화에 의해 응력 또는 변형유기 변태되 는 마르텐사이트 크기가 미세화되어 균열 전파를 억제할 수 있는 효과를 나타내게 됨으로써 상온충격인성 개선에 기여하는 것으로 생각된다.

그림 7은 상온충격시험 후 관찰한 합금 I과 II의 파면이 다. 합금 I과 II의 파면에서 모두 준벽개파괴 특성이 확인 되었다. 특히 합금 I $(0.8 \mathrm{C})$ 의 경우에는 파면상에 화살표로 표시한 취성파면 부분이 관찰되었다 (그림 $7 \mathrm{a}$ ). 이러한 취성파면은 균열이 전파하면서 미세조직에 존재하고 있던 잔류 오스테나이트가 응력 또는 변형유기 마르텐사이트로 변태되면서 발생한 것이라 판단된다 $[22,23,34]$. 조대한 잔 류 오스테나이트가 거의 관찰되지 않았던 합금 II $(0.6 \mathrm{C})$ 의 파면에서는 취성파면이 거의 관찰되지 않았다 (그림 7 b). 이러한 결과는 조대한 잔류 오스테나이트가 충격인성을 저해하는 미세조직학적 인자이며 $\mathrm{C}$ 함량 저감에 의한 오 스테나이트 미세화가 충격인성 개선에 일정 부분 역할을 하고 있음을 의미한다 [22,23,34].

그림 8과 표 2에 합금 I과 II의 대표적 응력-변형율 곡 선과 인장특성을 정리하였다. 경도 및 충격인성 변화와 유 사하게 $\mathrm{C}$ 함량 저감에 의해 합금의 항복강도와 인장강도

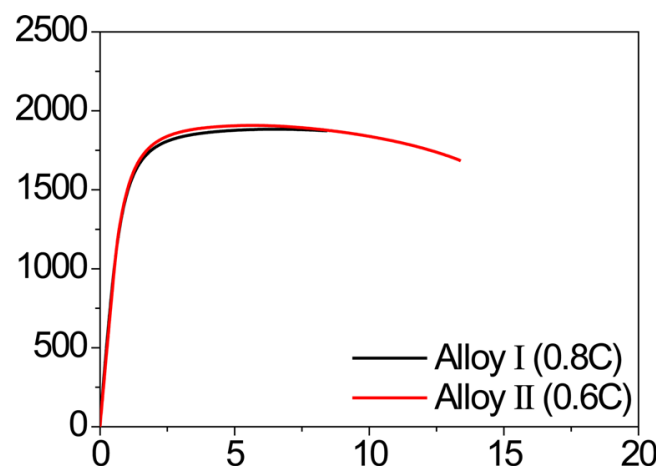

Fig. 8. Representative stress-strain curves of alloy I and II subjected to isothermal treatment at $250{ }^{\circ} \mathrm{C}$.

Table 2. Average tensile properties of investigated alloy I and II.

\begin{tabular}{cccc}
\hline & $\begin{array}{c}\text { Yield strength } \\
(\mathrm{MPa})\end{array}$ & $\begin{array}{c}\text { Tensile Strength } \\
(\mathrm{MPa})\end{array}$ & Elongation (\%) \\
\hline Alloy I & 1420 & 1883 & 8.4 \\
\hline Alloy II & 1474 & 1907 & 13.3 \\
\hline
\end{tabular}

가 다소 증가하였고, 총연신율 또한 증가하는 경향을 나타 내었다. 두 합금 모두 나노크기의 베이나이트와 잔류 오스 테나이트로 이루어진 미세조직을 가지고 있고, 주된 미세 조직학적 차이는 잔류 오스테나이트 분율과 크기라는 점을 고려할 때, 이러한 기계적 특성의 변화는 잔류 오스테나이 트 특성을 제어하는 것이 초고강도 베이나이트강의 높은 강도를 유지하면서, 인성 및 연성을 개선할 수 있는 유력 한 방안 중의 하나임을 의미한다.

\section{3. 항온변태온도에 따른 미세조직과 기계적 특성}

합금 II 를 200,250 및 $300^{\circ} \mathrm{C}$ 에서 각각 250,72 , 8 시간 항온변태처리 후 관찰한 미세조직들 간에는 상당한 차이가 확인되었다 (그림 9). 항온변태온도의 감소에 따라 베이니틱 페라이트 결정립의 크기가 점차 미세화되고 미세 조직이 치밀해지며, 이와 동반하여 잔류 오스테나이트 분 율이 감소하는 것을 알 수 있다. 베이니틱 페라이트 결정 립 크기가 미세화되는 것은 변태온도가 낮아짐에 따라 베 이니틱 페라이트 핵생성 구동력이 증가하기 때문이다. 또 한 항온변태온도가 감소하면 전단변태를 위한 구동력이 증 가하여 더 높은 분율의 베이니틱 페라이트가 형성될 수 있 으므로 잔류 오스테나이트 분율이 감소하는 결과를 가져오 게 된다.

합금 II 의 항온열처리 온도에 따른 기계적 특성의 변화 를 그림 $10 \mathrm{a}$ 와 b에 나타내었다. 항온열처리 온도가 낮 아질수록 합금의 경도는 상승하였다. 경도의 증가는 앞 절 

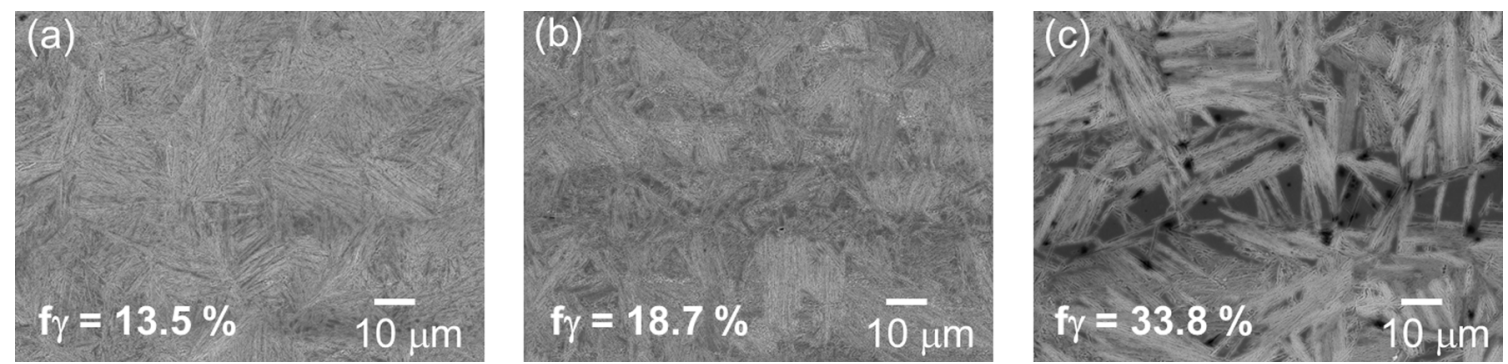

Fig. 9. Microstructure of alloy II after isothermal treatment at (a) $200{ }^{\circ} \mathrm{C}$, (b) $250{ }^{\circ} \mathrm{C}$ and (c) $300{ }^{\circ} \mathrm{C}$.
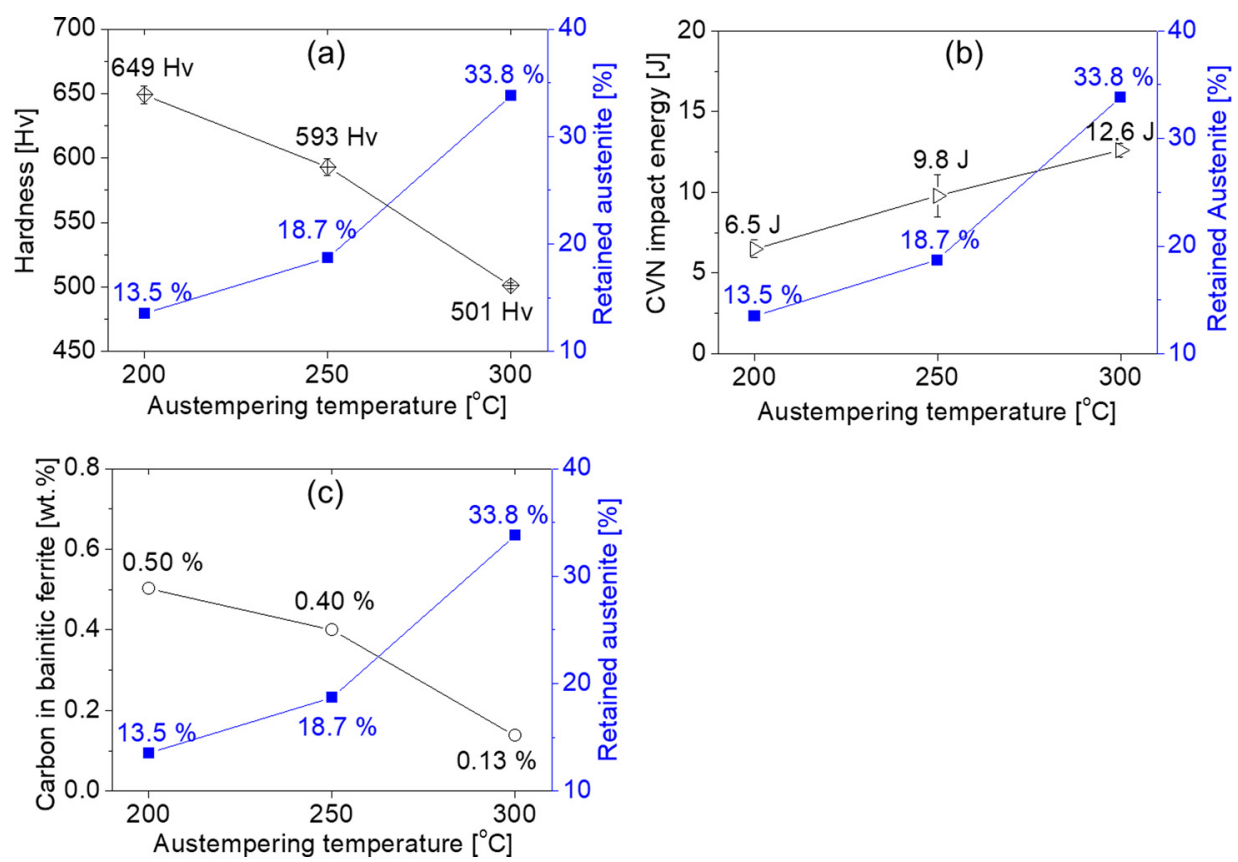

Fig. 10. (a) Hardness, (b) Charpy impact energy and (c) carbon content in bainitic ferrite of alloy II depending on the isothermal treatment temperature.

의 결과 (그림 $5 \mathrm{a}$ )와 유사하게 오스테나이트 분율 감소와 동반하는 것으로 나타났고, 이는 경질상인 미세한 베이니 틱 페라이트 분율 증가가 경도의 변화에 영향을 미치고 있 음을 의미한다. 뿐만 아니라 항온변태온도의 감소는 기지 상인 베이니틱 페라이트를 미세화시키고, 베이니틱 페라이 트 내 고용 $\mathrm{C}$ 농도를 증가시킴으로써 경도 상승을 더욱 촉진하는 것으로 생각된다 [25]. 구성상 분율 변화를 고려 할 때, 경도 변화가 합금의 $\mathrm{C}$ 함량 영향 (그림 $5 \mathrm{a}$ ) 보다 항온변태온도의 영향 (그림 $10 \mathrm{a}$ )에 더욱 크게 영향을 받 는 것은 그러한 이유에 기인한다. 실제로 구성상 분율 및 잔류 오스테나이트 내 $\mathrm{C}$ 농도로부터 계산한 베이니틱 페 라이트 내 $\mathrm{C}$ 농도를 보면 (그림 $10 \mathrm{c}$ ), 항온변태온도가 감소할수록 베이니틱 페라이트 내 고용 $\mathrm{C}$ 농도는 현저히 증가하고 있다. $\mathrm{C}$ 는 베이니틱 페라이트의 중요한 고용강
화 원소이므로, 고용 $\mathrm{C}$ 의 증가는 기지조직인 베이나이트의 경도를 상승시키는 주요한 인자이다. 또한 베이니틱 페라 이트 내 고용 상태로 존재하는 $\mathrm{C}$ 농도가 증가할수록 항온 변태에 동반하여 오스테나이트로의 재분배 되는 $\mathrm{C}$ 의 양이 작아지게 된다. 이는 오스테나이트 내 $\mathrm{C}$ 농축이 원활하게 이루어지지 못하는 결과를 초래하므로 베이니틱 페라이트 변태를 더욱 촉진하여 경질상 분율 증가를 가져온다.

항온변태온도에 따른 상온충격인성변화는 앞 절과 비교 하여 다소 상이한 결과를 나타내었다. 동일한 항온변태온도 조건에서 $\mathrm{C}$ 함량만 다른 경우에는 (그림 $5 \mathrm{~b}$ ), 잔류 오스테 나이트 분율이 증가하면 충격인성이 열화 되었으나, 동일한 $\mathrm{C}$ 함량에서 항온변태온도가 달라지는 경우에는 (그림 10 b) 잔류 오스테나이트 분율이 증가하여도 충격인성이 상승 하였다. 이러한 결과는 항온변태온도가 변화하는 경우에는 
잔류 오스테나이트의 특성 변화뿐만 아니라 기지조직인 베 이니틱 페라이트 특성이 변화하여 충격인성에 영향을 미치 기 때문이다. 그림 $10 \mathrm{c}$ 에 나타낸 바와 같이, 항온변태온 도가 감소하면 베이니틱 페라이트 내 고용 $\mathrm{C}$ 함량이 현저 히 증가하게 된다 [6,25-29]. 이러한 고용 C 의 증가는 매우 높은 강화효과를 나타냄과 동시에 인성의 열화를 초 래하게 된다 [30]. 즉 항온변태온도가 낮아지면 상당한 수 준의 $\mathrm{C}$ 가 베이니틱 페라이트 내에 고용된 상태로 존재하게 되고, 이 때 기지조직인 베이니틱 페라이트의 특성은 취성 이 강한 마르텐사이트와 유사하게 된다. 따라서 항온변태 온도가 낮아짐에 따라 조대한 잔류 오스테나이트 분율이 감소하여 상온충격인성 측면에서 유리한 영향을 미칠 수 있지만, 이와 동시에 기지조직인 베이니틱 페라이트의 취 성이 증가하게 되고, 이러한 기지조직 취성 증가 영향이 보다 지배적으로 작용하기 때문에 항온변태온도가 낮아짐 에 따라 상온충격인성이 열화되는 것으로 판단된다. 그림 11 은 $200{ }^{\circ} \mathrm{C}$ 와 $300{ }^{\circ} \mathrm{C}$ 에서 항온변태 처리한 합금 II의 충격파면이다. $200{ }^{\circ} \mathrm{C}$ 의 경우에는 준벽개파면이 주로 관 찰되지만, 항온변태온도가 $300{ }^{\circ} \mathrm{C}$ 로 상승하게 되면 화살표 부분처럼 (그림 11 b) 일부 연성파면을 관찰할 수 있다. 이러한 결과는 항온변태온도의 증가에 의해 기지조직인 베 이니틱 페라이트의 인성이 어느 정도 회복되었음을 의미한
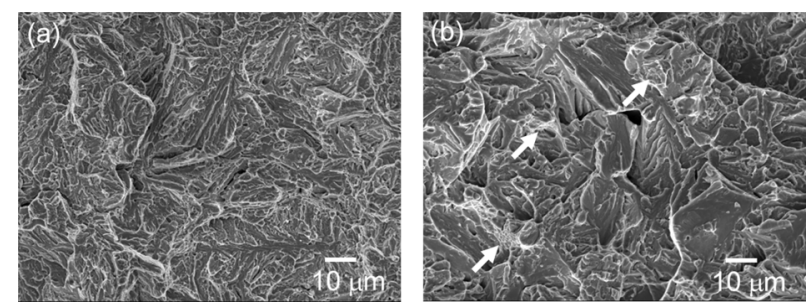

Fig. 11. Fracture surface of alloy II after Charpy impact test: (a) isothermal treated at $200{ }^{\circ} \mathrm{C}$ and (b) $300{ }^{\circ} \mathrm{C}$.

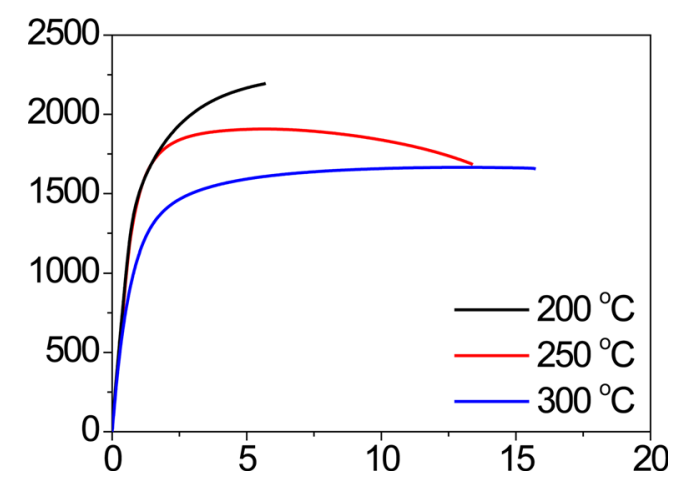

Fig. 12. Representative stress-strain curves of alloy II depending on isothermal treatment temperature.
Table 3. Average tensile properties of alloy II depending on isothermal transformation temperature.

\begin{tabular}{cccc}
\hline & $\begin{array}{c}\text { Yield strength } \\
(\mathrm{MPa})\end{array}$ & $\begin{array}{c}\text { Tensile Strength } \\
(\mathrm{MPa})\end{array}$ & Elongation (\%) \\
\hline $200^{\circ} \mathrm{C}$ & 1469 & 2192 & 5.7 \\
\hline $250^{\circ} \mathrm{C}$ & 1474 & 1907 & 13.3 \\
\hline $300^{\circ} \mathrm{C}$ & 956 & 1665 & 15.7 \\
\hline
\end{tabular}

다. 항온변태온도 저하에 따라 항복강도와 인장강도는 현 저히 증가하지만, 이에 반하여 연신율의 급격한 감소를 나 타내는 인장실험 결과는 (표 3 및 그림 12) 경도 및 상온 충격시험 결과와 일치하는 경향을 나타내고 있다.

\section{4. 고찰 및 결론}

본 연구에서 사용한 합금 $\mathrm{II}$ 는 나노 스케일의 초고강도 베이나이트를 얻을 수 있는 것으로 보고된 $200 \sim 300{ }^{\circ} \mathrm{C}$ 온도 범위에서 항온변태처리가 가능할 것으로 생각되는 최 소한의 수준 $(0.6 \mathrm{wt} \%)$ 으로 $\mathrm{C}$ 함량을 저감한 합금이다. $\mathrm{C}$ 함량이 저감된 합금 $\mathrm{II}$ 는 기존에 보고된 $0.8 \mathrm{wt} \%$ 수준 이상의 초고강도 베이나이트 강재와 비교하여 동등 이상의 강도수준을 유지하면서 향상된 충격인성을 나타냄을 확인 하였고, 이는 충격인성에 불리한 영향을 미치는 조대한 잔 류 오스테나이트 분율 감소에 기인하는 것으로 판단된다. 이러한 결과는 초고강도 베이나이트 강재 적용분야 확대를 위해 필수적이라고 생각되는 상온충격인성을 개선하기 위 한 합금설계 방안으로 $\mathrm{C}$ 함량 제어가 중요한 인자임을 시 사하고 있다. C 함량 저감에 따라 합금의 경화능은 감소한 다. 따라서 오스테나이트화 처리 이후 항온변태온도로 냉 각하는 과정에서 충분한 냉각속도를 확보하기 어려운 경우 에는 고온 변태상이 생성되어 목표로 하는 미세조직과 기 계적 특성을 확보하기 어려워질 가능성이 있다. 이 때문에 기존 $0.8 \mathrm{wt} \%$ 수준 이상의 $\mathrm{C}$ 함량을 가지는 초고강도 베 이나이트 강재의 장점 중의 하나로 알려지고 있는 오스테 나이트화 처리 이후 비교적 자유로운 냉각조건을 합금 II 에 적용하기 어려울 것으로 생각된다. 본 연구의 경우에서 도 나노 스케일의 베이나이트를 확보하기 위해서는 오스테 나이트화 처리 이후 약 $30{ }^{\circ} \mathrm{C} / \mathrm{s}$ 수준의 비교적 빠른 냉각 속도가 요구되었다. 하지만, 냉각속도 제약에도 불구하고 초고강도 베이나이트강의 낮은 충격인성 개선을 위해서는 $\mathrm{C}$ 함량 저감이 불가피하다고 판단된다.

$\mathrm{C}$ 함량이 저감된 합금에 있어서도 미세조직과 물성의 최 적화를 위해서는 적절한 온도에서의 항온변태 처리가 필수 
적이다. 항온변태온도가 낮아지면, 베이나이트 변태가 촉진 되어 잔류 오스테나이트 분율이 감소하고, 결정립 크기도 미세화된다. 하지만 잔류 오스테나이트 분율의 감소와 결 정립 미세화에도 불구하고, 상온충격인성은 항온변태온도 가 낮아질수록 저하되는 경향을 나타내었다. 이것은 기지 조직을 이루는 베이니틱 페라이트 결정립 내의 고용 $\mathrm{C}$ 농 도 증가로 인하여 기지조직의 인성이 낮아지게 되고 이에 기인한 충격인성 감소 효과가 잔류 오스테나이트 분율 감 소 및 미세화에 의한 충격인성 향상 효과 보다 지배적인 인자로 작용하기 때문이다.

\section{감사의 글}

본 연구는 국방과학연구소의 연구비 지원으로 수행되었 으며 이에 감사 드립니다.

\section{REFERENCES}

1. F. Caballero, H. Bhadeshia, K. Mawella, D. Jones, and P. Brown, Mater. Sci. Technol. 18, 279 (2002).

2. H. Bhadeshia, Mater. Sci. Technol. 21, 1293 (2005).

3. H. Bhadeshia, Proc. R. Soc. London Ser. A 466, 3 (2010).

4. I. Tamura, H. Sekine, and T. Tanaka, Thermomechanical processing of high-strength low-alloy steels, 202-235, Butterworth-Heinemann, UK (2013).

5. T. Sourmail and V. Smanio, Acta Mater. 61, 2639 (2013).

6. M. Hillert, L. Höglund, and J. Ågren, Metall. Mater. Trans. A 35, 3693 (2004).

7. H. K. Sung, S. Y. Shin, B. Hwang, C. G. Lee, N. J. Kim, and S. Lee, Korean J. Met. Mater. 48, 798 (2010).

8. H. Bhadeshia and D. Edmonds, Met. Sci. 17, 411 (1983).

9. H. Bhadeshia and D. Edmonds, Met. Sci. 17, 420 (1983).

10. B. Kim, C. d. Celada, D. San Martín, T. Sourmail, and P. Rivera-Díaz-del-Castillo, Acta Mater. 61, 6983 (2013).

11. B. Dönges, A. Giertler, U. Krupp, C.-P. Fritzen, and H.-J. Christ, Mater. Sci. Eng. A 589, 146 (2014).

12. S. Das, S. Kundu, and A. Haldar, Mater. Sci. Forum 702, 939 (2012).

13. D. J. Lee, M. S. Kim, G. E. Ku, S. H. Heo, N. Y. Kim, and J.-M. Lee, Korean J. Met. Mater. 56, 221 (2018).
14. C. Garcia-Mateo, F. G. Caballero, and H. K. D. H. Bhadeshia, ISIJ Int. 43, 1238 (2003).

15. I. Timokhina, P. Hodgson, and E. Pereloma, Metall. Mater. Trans. A 35, 2331 (2004).

16. Y. Xia, G. Miyamoto, Z. Yang, C. Zhang, and T. Furuhara, Acta Mater. 91, 10 (2015).

17. F. G. Caballero, C. Garcia-Mateo, M. Santofimia, M. K. Miller, and C. G. de Andrés, Acta Mater. 57, 8 (2009).

18. H. K. D. H. Bhadeshia and J. Christian, Metall. Trans. A 21, 767 (1990).

19. D. Quidort and Y. Bréchet, Scr. Mater. 47, 151 (2002).

20. N. Chester and H. Bhadeshia, J. Phys. IV Colloque 7, C541-C5-46 (1997).

21. D. Quidort and Y. J. Brechet, ISIJ Int. 42, 1010 (2002).

22. G. Gao, H. Zhang, X. Gui, P. Luo, Z. Tan, and B. Bai, Acta Mater. 76, 425 (2014).

23. Q. Zhou, L. H. Qian, J. Tan, J. Y. Meng, and F. C. Zhang, Mater. Sci. Eng. A 578, 370 (2013).

24. Y. Tomita and T. Okawa, Mater. Sci. Eng. A 172, 145 (1993).

25. H. Bhadeshia, Acta Metall. 28, 1103 (1980).

26. F. G. Caballero, M. K. Miller, and C. Garcia-Mateo, Acta Mater. 58, 2338 (2010).

27. A. Clarke, J. Speer, M. Miller, R. Hackenberg, D. Edmonds, D. Matlock, F. Rizzo, K. Clarke, and E. De Moor, Acta Mater. 56, 16 (2008).

28. F. G. Caballero, M. K. Miller, C. Garcia-Mateo, J. Cornide, and M. Santofimia, Scr. Mater. 67, 846 (2012).

29. C. Garcia-Mateo, J. A. Jiménez, H.-W. Yen, M. Miller, L. Morales-Rivas, M. Kuntz, S. Ringer, J.-R. Yang, and F. Caballero, Acta Mater. 91, 162 (2015).

30. G.-H. Kim, J.-H. Jang, S.-H. Kim, B.-J. Kim, K.-Y. Sohn, and D.-G. Nam, Korean J. Met. Mater. 55, 559 (2017).

31. C. F. Jatczak, SAE Trans. 1657-1676 (1980).

32. M. Deyer, D. Vanderschueren K. Ke Lauwe, and B. C. De Cooman, $41^{\text {st }}$ Mechancial Working and Steel Processing Proceedings, p.265, ISS, Toronto, Candna (1999).

33. Y. Guo, Z. Li, C. Yao, K. Zhang, F. Lu, K. Feng, J. Huang, M. Wang, and Y. Wu, Mater. Des. 63, 100 (2014).

34. R. Rana, S. Chen, A. Haldar, and S. Das, Arch. Metall. Mater. 62, 2331 (2017). 